\title{
Fund Raising from Hồ Chí Minh City Municipal Bonds: An Analysis and Policy Implications
}

\author{
Dương Thị Bình Minh \\ University of Economics HCMC \\ dbminh@ueh.edu.vn \\ Vũ Thị Minh Hằng \\ University of Economics HCMC \\ vuhangngoc16@yahoo.com.vn \\ Diệp Gia Luật \\ University of Economics HCMC \\ gialuat@ueh.edu.vn
}

\author{
Nguyễn Thị Mỹ Linh
rsity of Hochiminh City \\ Industrial University of Hochiminh City
mylinhdhen@ yahoo.com.vn \\ Phùng Thị Cẩm Tú \\ Industrial University of Hochiminh City \\ phungcamtu@yahoo.com \\ Đào Thị Minh Huyền \\ University of Economics HCMC \\ minhhuyen@ueh.edu.vn
}

\begin{tabular}{|c|c|}
\hline ARTICLE INFO & ABSTRACT \\
\hline $\begin{array}{l}\text { Article history: } \\
\text { Received: } \\
\text { May 10, } 2013 \\
\text { Received in revised form } \\
\text { June 04, } 2013 \\
\text { Accepted: } \\
\quad \text { Sep. } 25,2013 \\
\end{array}$ & $\begin{array}{l}\text { Sources of capital held by the public and economic sectors offered } \\
\text { great potential. Municipal bonds issued by HCMC government help } \\
\text { mobilize these sources of funds for socioeconomic and infrastructure } \\
\text { development. The determination of demands for funds and ability to } \\
\text { efficiently raise them greatly dependant on technique of raising funds } \\
\text { through issues of bonds, and this was always considered a topical and } \\
\text { important issue. This paper performed an analysis, carried out } \\
\text { evaluation on methods and effects concerning the issue of the HCMC } \\
\text { municipal bonds, and proposed solutions to technical mechanisms } \\
\text { with a view to beefing the process of raising this source of capital for } \\
\text { infrastructure development based on HCMC specific conditions. }\end{array}$ \\
\hline
\end{tabular}




\section{INTRODUCTION}

Mobilization of investments has produced many positive effects on HCMC economic development, especially on its growth rate, export growth, revenues for the state budget and establishment of industrial parks and export processing zones - gateway to foreign markets for the City. Mobilization of capital through infrastructure bonds has been carried out in HCMC in the past, but it is not implement regularly and laws, policies, and mechanisms for mobilizing these funds suffer from several deficiencies.

The city authorities have not had a strategic and comprehensive plan to mobilize, exploit, and use these funds effectively. Thus, a study to improve mechanisms and draw up long-term strategies for fund mobilization to develop infrastructure is necessary. This paper focuses on the analysis and evaluation of the mobilization of capital through municipal bonds and proposes solutions to improvement in such mechanisms as an effective way to promote socioeconomic development in HCMC.

\section{DATA AND RESEARCH METHODS}

This paper collected secondary data from such trustworthy statistical sources as Statistical Yearbook, HCMC Statistics Office, HCMC Investment and Planning Department, HCMC Department of Finance, HCMC Finance and Investment Stateowned Company, HCMC People's Committee, and other relevant government agencies.

The principal methods like statistics, qualitative analysis, and synthesis are used in the research to evaluate the fund raising through municipal bonds and propose recommendations.

\section{MOBILIZING FUNDS THROUGH MUNICIPAL BONDS}

\section{a. Municipal Bond:}

Municipal bond is a kind of debt instrument on financial market, confirming the obligation of the issuers to pay both principal and interest on a specified date.

Bonds in general and municipal bonds in particular all have their par values, reflecting the commitment of the issuers that money will be returned to bondholders at a maturity date at a specified interest rate. The interest is paid on a regular basis and determined before the issue of the bonds.

The two basic types of municipal bonds on financial markets are general obligation bonds and revenue bonds. Municipal bonds ensure basic features of debt securities to be listed and traded on stock markets. 
- Issuers: The issuers are people's committees of cities/ provinces directly responsible to the central government.

- Bond term: Municipal bonds have a one-year term or longer that is specifically decided by provincial people's committee in accordance with the demand for capital and market conditions.

- Rights of bondholders: Repayment of both principal and interest when due is guaranteed by provincial/municipal people's committee. Such bonds can also be sold, gifted, inherited, mortgaged, and discounted.

- Interest: The interest rate of municipal bonds is decided by issuers in each issue, and it may be based on fixed, floating, and discount rate as approved by the authority.

- Fund for repayment: Repayment of bond principal and interest are obtained from provincial budget or income from projects financed by municipal bonds.

Due to their features and high liquidity in comparison with other types of bonds in the market, municipal bonds have high levels of safety.

\section{b. Capital Mobilization:}

Municipal bonds are a tool to mobilize investment for socioeconomic development, especially the infrastructure building. Therefore, the determination of demands for capital to be mobilized through bond issuance must be based on the following basic factors:

- Objectives and tasks of local socioeconomic development during the year and in the medium and long-term plan,

- Economic growth rate,

- Required gross investment for local development,

- Employment/unemployment rate, traffic index and other indexes relating to social welfare,

- Structural changes, replacement of technologies, local development of human resources, and so on.

The determination of the size of fund to mobilize through municipal bonds depends on whether the bonds are general obligation bonds or revenue bonds.

Municipal bonds are traded on the stock exchange. To ensure the benefits and credibility of the issuers, increase the attractiveness and safety of the bonds, and protect 
the investors, credit ratings of municipal bonds are to be determined. These are based on an analysis of the following basic factors:

(1) Legal framework and delegation of authority

(2) Local economic potentials

(3) Managerial and administrative capacity of local governments

(4) State of local budget and fiscal policy

(5) State of debt, solvency, size of local public debt, and

(6) Special sponsorship and supplement.

Among those factors, the first five ones determine the independent credit ratings of local authorities. The last one particularly assesses possibilities of securing special financial support from the central government in case of bankruptcy or insolvency.

Several methods of issuance, such as underwriting, issuing agency, auction on stock exchange, and retail through financial organizations can be flexibly applied. The determination of interest rate is based on that of government bonds of the same term, and average bank interest rate or market interest rate through competitive auction.

Financial sources for repayment of principal and interest of the bonds are extracted from tax and fee revenues collected by provincial/municipal authority for general obligation bonds and from direct income in the form of fees from projects that was put into operation for revenue bonds. Payment terms can be one or a combination of the following: (1) Repayment of principal - The principal can be repaid completely on the maturity date or by installments of yearly, monthly, or quarterly basis according to state of the local budget income. The repayment terms should be determined and publicized before issuance; and (2) Repayment of interest - repayment is done periodically depending on types of municipal bonds issued.

\section{EXPERIENCE OF ISSUING MUNICIPAL BONDS FROM FOREIGN COUNTRIES}

Developed countries have successfully issued municipal bonds for infrastructure development. An essential factor that contributes to such success is their well-developed legal system that facilitates a healthy financial market, and ensures rights and benefits of both local authorities and investors.

As for developing nations, this form of capital mobilization is rather severely hampered by limited financial resources, lending capacity, and experience and managerial skills of local authorities. Additionally, financial regulations and the legal 
framework for bond market in these countries have not been fully designed. Foreign experience offers the following lessons of developing the bond market in a sustainable way:

- A legal framework for municipal bond market should be enacted and completed and this should include national budget law, securities law, and tax law, etc. Obviously, a clear, logical, and perfectly feasible legal system is considered as an indispensable factor crucial for the formation and development of municipal bond markets.

- Financial market should be developed. New policies to support financial intermediaries taking part in the bond market and providing advisory services should be adopted. Optimal conditions are to be created to encourage the improvement of secondary bond markets and facilitate the growth in liquidity for bonds, especially municipal ones.

- Creditworthiness of municipal bonds needs improving. Local authorities should take measures to ensure debt repayment when due, such as buying bond insurance and asking for guarantee from the central authorities to enhance credit rating for local bonds.

- Delegation of financial control should be carried out properly.

- Policies on income tax should be appropriate.

- Transparent information is ensured by designing certain standards of financial disclosure and enabling investors to access reliable sources of information.

\section{ANALYSIS OF FUND RAISING FROM MUNICIPAL BONDS}

\section{a. Municipal Bond Market: Demands and Investment:}

Early in 1994, HCMC People's Committee asked for permission from the Finance Ministry to issue municipal bonds (as a pilot scheme) to finance the project of Nguyễn Tất Thành Street. Total investment of the project is VND41.8 billion and 30 billion of which would be from municipal bonds. The bonds bear an interest rate of $15 \%$ a year in three-year term and are secured by the city's budget.

After Decree 93/2001/NĐ-CP on delegation of authorities in certain fields in HCMC which allowed the city to issue such municipal bonds was promulgated in 2001, the size of issued capital, needed investment and HCMC budget revenues in the period 20032007 (Table 1) experience the following changes:

- In 2003, the city issued VND2,000 billion worth of two-year and five-year-term municipal bonds and collected a total of 1,500 billion from many financial institutions 
and banks. The retail of municipal bonds are made through HCMC Securities Corporation (issuance underwriter and issuance agency), branches of the State Treasury, commercial banks, and Postal Savings Service Company, etc. Through the two issues, the bonds with an interest rate of $8.52 \%$ per year for two-year bonds and $9.00 \%$ per year for five-year ones attracted many investors.

- In 2004, the proceeds from bonds were VND2,000 billion and 80\% of which (or VND 1,600 billion) were from 5-year bonds and 20\% (VND400 billion) were from 10year ones. The issuance of the bonds was planned by the HCMC Investment Fund for Urban Development (HIFU).

- In April 2005, 5-year bonds with interest rates of $8.95 \%$ and $9.45 \%$ a year were issued.

- In 2006, HCMC People's Committee issued municipal bonds through HIFU. Bonds came up with the par value of VND100,000 for 10-year and 15-year terms and interest rates of $9.25 \%$ and $9.55 \%$ a year respectively. Although the issuer paid more attention to liquidity of the bonds to attract more investors, trade in bonds was not busy as expected with the result that the city still suffered a shortage of fund for development.

- In 2007, three types of municipal bonds of the same face value of VND100,000 offer relatively low interest rates $-7.8 \%, 8.5 \%$, and $8.8 \%$ for the term of 5,10 , and 15 years respectively, which made investors only purchase 10 - and 15 -year bonds and refused the 5-year ones.

Table 1: Scale of Issued Capital, Demand for Investment and HCMC Budget Revenue in 2003-2007 (VND billion)

\begin{tabular}{|c|c|c|c|c|c|c|}
\hline \multirow[b]{2}{*}{ Year } & \multirow{2}{*}{$\begin{array}{c}\text { HCMC } \\
\text { Budget } \\
\text { Revenue }\end{array}$} & \multirow{2}{*}{$\begin{array}{l}\text { Demand for } \\
\text { Investment }\end{array}$} & \multirow{2}{*}{$\begin{array}{c}\text { Demand for } \\
\text { Investment from } \\
\text { State Budget }\end{array}$} & \multicolumn{3}{|c|}{ Sources of Investment } \\
\hline & & & & $\begin{array}{c}\text { State } \\
\text { Budget }\end{array}$ & Bonds & Others \\
\hline 2003 & 42,456 & 35,500 & 10,000 & 3,500 & 2,000 & 4,500 \\
\hline 2004 & 47,457 & 40,500 & 10,000 & 2,750 & 2,000 & 5,250 \\
\hline 2005 & 54,354 & 53,000 & 11,500 & 4,400 & 2,000 & 5,100 \\
\hline 2006 & 67,254 & 62,000 & 12,500 & 4,700 & 2,000 & 5,800 \\
\hline 2007 & 77,959 & 74,500 & 13,000 & 3,000 & 2,000 & 8,000 \\
\hline
\end{tabular}


Source: Websites of Ministry of Finance, HCMC Department of Finance, Solutions for the issuance of municipal bonds

In 2009 municipal bonds for toll-generating public works, particularly for the project of Thủ Thiêm New Urban Area, with a plan to issue VND4, 000 billion worth of bonds. In fact, underwriters raised VND1, 540 billion from 3-year and 5-year bonds with an interest rate of $10.4 \%$ per year (see Table 2). Most underwriters are commercial banks. However, proceeds from the issuance of municipal bonds for toll-generating projects were not as high as planned. Only one of auctions held at Hà Nội Stock Exchange, equaling $0.6 \%$ of the planned target, produced good bids, interest rates offered by investors were much higher than the interest rate ceiling.

Facts of issuance of municipal bonds in the past decade showed that the bond market was not much active and its development was very limited. Trade in bonds on stock markets could not draw attention from issuers; capital raised from bonds was very small in comparison with the need for investment in infrastructure; and the bonds failed to attract the attention of investors due to their long terms and low interest rate ceiling. In each issue of municipal bonds, HCMC Department of Finance and HIFU (lately renamed as Finance and Investment State-owned Company - HFIC) along with other departments and agencies are usually assigned the task of persuading financial institutions and banks to buy bonds.

Table 2: Issuance of Municipal Bonds in HCMC (VND billion)

\begin{tabular}{|c|c|c|c|c|c|c|c|c|c|c|c|}
\hline \multirow{2}{*}{ Year } & \multicolumn{2}{|c|}{ 2-year term } & \multicolumn{2}{|c|}{3 -year term } & \multicolumn{2}{|c|}{5 -year term } & \multicolumn{2}{|c|}{10 -year term } & \multicolumn{2}{|c|}{15 -year term } & \multirow{2}{*}{$\begin{array}{l}\text { Total } \\
\text { Value }\end{array}$} \\
\hline & \multicolumn{2}{|c|}{ Value Interest Rate* } & \multicolumn{2}{|c|}{ Value Interest Rate* } & Value & Interest Rate* & Value & Interest Rate* & Value & Interest Rate* & \\
\hline 2003 & & 8.52 & & & 1,800 & 9.0 & & & & & 2,000 \\
\hline 2004 & & & & & 1,600 & $8.5-8.7$ & 400 & 9.0 & & & 2,000 \\
\hline 2005 & & & & & 1,035 & $9.0-9.05$ & & & 965 & 9.55 & 2,000 \\
\hline 2006 & & & & & 850 & $8.8-9.05$ & 525 & $9.15-9.25$ & 625 & $9.25-9.55$ & 2,000 \\
\hline 2007 & & & & & 756 & 8.50 & 742 & & 502 & & 2,000 \\
\hline 2008 & & & & & & & & & & & \\
\hline 2009 & & & 1,540 & 10.4 & & & & & & & 1,540 \\
\hline 2010 & & & & & & & & & & & \\
\hline 2011 & & & & & & & & & & & \\
\hline Total & 200 & & 1,540 & & 6,041 & & 1,667 & & 2,092 & & 11,540 \\
\hline
\end{tabular}

Note: * means \%/year

Source: HCMC Department of Finance. 


\section{b. Determination of Credit Ratings:}

Credit ratings of municipal bonds, since their first issue in 2003, have not been conducted through calculations and analyses of financial indicators by an independent credit rating agency at home (not existed so far) or abroad. In fact, for issues of the bonds from 2003 up until now, the determination of bond credit ratings has been based on the following factors:

- Economic potentials and the city's budget income:

The issued municipal bonds are general obligation ones whose repayment is guaranteed by the local budget; therefore, if placed in relation to HCMC economic potentials and budget income, repayment of bond is highly ensured. Meanwhile, from 2003 up to now, proceeds from sale of bonds have been too small, so even if credit ratings have not been conducted, the bonds still earn investors' trust.

- Liquidity of the bonds:

Municipal bonds are traded on the financial market. As for institutional investors like commercial banks, financial companies, and insurance companies, etc. the bonds are regarded as an investment that can produce profits and meet the liquidity demands in case of cash shortage. This advantage made the issues of bonds in 2005-2007 successful with financial institutions and banks as their main buyers although the stock markets witnessed unfavorable fluctuations.

\section{c. Issuance Methods:}

The issuance of municipal bonds is based on legal regulations, and the methods having been applied since 2003 include:

- Underwriting and issuance agency: In this method, bonds are issued through securities companies, commercial banks and banking institutions that are allowed by law to perform this function. The method, mainly applied in the issuance of municipal bonds between 2003 and 2007, ensures the quantity and par value of the bonds issued and save time and costs. Especially in 2007 and 2009 when the stock market was unpredictable, municipal bonds were no longer attractive to investors. The HCMC government had municipal bonds issued by commercial banks as underwriters and succeeded in raising necessary funds as planned. 
- Auction on the Stock Exchange: Bonds are issued in lots by holding noncompetitive and competitive biddings on the Stock Exchange with selling prices equal to the par value.

- Retail method: only applicable to 2-year bonds for the issuance in 2003.

In brief, in the years $2003-2005,71 \%$ of the total bonds sold were issued through underwriters, 7\% through biddings on Stock Exchange, and 22\% through HCMC Securities Corporation as a retailer.

Since 2006, the stock exchange and bond market witnessed unpredictable fluctuations, which made investors lose interest in auctions of municipal bonds. To ensure the success, the issuers mainly applied underwriting method and aimed at financial institutions and banks as primary investors. After four years of issuance, out of the total value of VND6,840 billion mobilized, underwriting method made up 5,756 billion (81.5\%) whereas bidding method accounted for 1,084 billion (18.5\%) (Table 3).

Table 3: Issuance Methods in 2006-2012 (VND billion)

\begin{tabular}{cccc}
\hline Year & Retail & Underwriting & Auction \\
\hline 2006 & - & 2,000 & - \\
2007 & - & 916 & 1,084 \\
2009 & - & 1,540 & - \\
2012 & - & 3,300 & - \\
\hline Total & - & 5,756 & 1,084 \\
\hline
\end{tabular}

Source: Report of HCMC Investment Fund for Urban Development (HIFU)

\section{d. Borrowing Rate:}

The interest rate for municipal bonds is based on the interest rate offered by government bonds of the same term issued in the same period, plus a difference resulted from the fact that the safety level of government bonds is higher than that of municipal bonds $(0.06 \%$ for every year of the term). As for bidding, interest rate is decided by bidding results within the actual interest rate of government bonds of the same term at the issuance date plus a margin decided by the Minister of Finance. 
Table 4: Quantity of Municipal Bonds and Interest Rate Offered in 2003-2007 (VND billion)

\begin{tabular}{ccc|cc|cc|cc|c}
\hline \multirow{2}{*}{ Type } & \multicolumn{2}{|c|}{2 year } & \multicolumn{2}{|c|}{5 year } & \multicolumn{2}{c|}{10 year } & \multicolumn{2}{c|}{15 year } & \multirow{2}{*}{$\begin{array}{c}\text { Total } \\
\text { Value }\end{array}$} \\
\cline { 2 - 7 } & Quantity & $\begin{array}{c}\text { Interest } \\
\text { Rate* }\end{array}$ & Quantity & $\begin{array}{c}\text { Interest } \\
\text { Rate* }\end{array}$ & Quantity & $\begin{array}{c}\text { Interest } \\
\text { Rate* }\end{array}$ & Quantity & $\begin{array}{c}\text { Interest } \\
\text { Rate* }\end{array}$ & 2,000 \\
\hline 2003 & 200 & 8.52 & 1,800 & 9.0 & - & - & - & - & 2,000 \\
2004 & - & - & 1,600 & $8.5-8.75$ & 400 & 9.0 & - & - & 2,000 \\
2005 & - & - & 1,035 & $8.9-9.15$ & - & - & 965 & $9.4-9.65$ & 2,000 \\
2006 & - & - & 850 & 9.0 & 525 & 9.25 & 625 & 9.55 & 2,000 \\
2007 & - & - & 756 & $7.8-8.5$ & 742 & $7.9-8.8$ & 502 & $8.25-9.0$ & 2,000 \\
\hline Total & 200 & & 6,041 & & 1,667 & & 2,092 & & 10,000 \\
\hline
\end{tabular}

Note: * means \%/year

Source: Report of HCMC Investment Fund for Urban Development (HIFU)

In 2009, HCMC issued municipal bonds for the project of Thủ Thiêm New Urban Area. The total volume of bonds is worth VND4,000 billion. However, due to unfavorable changes in the economy, the city conducted 5 issues including three underwriting ones and two bidding ones which raised only VND1,540 billion with interest rates ranging from 10.4\%/year to $10.5 \%$ year. Total bond issuance volume equaled only $38.5 \%$ of the planned target, and the issues were all conducted through underwriting method.

Table 5: Issues of HCMC Municipal Bonds in 2009 (VND billion)

\begin{tabular}{cccccccc}
\hline Session & $\begin{array}{c}\text { Issuance } \\
\text { Date }\end{array}$ & $\begin{array}{c}\text { Methods of } \\
\text { Issuance }\end{array}$ & Maturity & $\begin{array}{c}\text { Stated } \\
\text { Volume }\end{array}$ & $\begin{array}{c}\text { Interest } \\
\text { Rate } \\
(\% / \text { year })\end{array}$ & $\begin{array}{c}\text { Issued } \\
\text { Volume }\end{array}$ & $\begin{array}{c}\text { Number of } \\
\text { Participants }\end{array}$ \\
\hline 1 & $\begin{array}{c}\text { Aug. 31, } \\
2009\end{array}$ & Underwriting & 3 years & 1,000 & $10.4 \%$ & 1,000 & 6 \\
2 & $\begin{array}{c}\text { Sep. 5, } \\
2009\end{array}$ & Bidding & 5 years & 500 & $10.5 \%$ & 0 & 0 \\
3 & $\begin{array}{c}\text { Sep. } 15, \\
2009\end{array}$ & Underwriting & 3 years & 2,000 & $10.4 \%$ & 500 & 3
\end{tabular}




\begin{tabular}{|c|c|c|c|c|c|c|c|}
\hline 4 & $\begin{array}{c}\text { Sep. } 28 \\
2009\end{array}$ & Bidding & 5 years & 500 & $10.5 \%$ & 0 & 0 \\
\hline & $\begin{array}{c}\text { Sep. } 30 \text {, } \\
2009\end{array}$ & Underwriting & 3 years & 2,500 & $10.4 \%$ & 40 & 2 \\
\hline
\end{tabular}

Source: Report of HCMC Investment Fund for Urban Development (HIFU)

Considering interbank interest rate in early 2009, we see that that borrowing and lending rates in the VND were as stable as the base rate. However, upheavals appeared in the second half of the year. From July to November, commercial banks constantly increased borrowing rate in the VND, focusing on long-term deposits and putting pressure on short-term ones. The maximum rate reached the highest peaks of 9\%, 10\% and 10.5\%/year. The concept of "interest curve" was blurred when many members uniformly applied a high level for most of the terms. As soon as the SBV decision to raise the base rate from 7\% to 8\% as from Dec. 1, 2009 was made, many commercial banks increased the borrowing rate, even to a level as high as 10.5\%/year (not to mention other bonuses). Fluctuations in interest rates in the second half of 2009 reflected liquidity problems of commercial banks. During September and October 2009 the average interbank rates also increased.

Table 6: Average Interbank Interest Rate in 2009 (\%/year)

\begin{tabular}{llllllll}
\hline \multirow{2}{*}{ Term } & Overnight & $\begin{array}{c}\text { One } \\
\text { Week }\end{array}$ & $\begin{array}{c}\text { Two } \\
\text { Weeks }\end{array}$ & $\begin{array}{c}\text { One } \\
\text { Month }\end{array}$ & $\begin{array}{c}\text { Three } \\
\text { Months }\end{array}$ & $\begin{array}{c}\text { Six } \\
\text { Months }\end{array}$ & 12 Months \\
\hline VND & 7.25 & 8.58 & 8.98 & 8.87 & 9.90 & 10.18 & 9.81 \\
USD & 0.91 & 1.21 & 1.06 & 1.78 & 2.22 & 1.89 & - \\
\hline
\end{tabular}

Source: SBV (2009)

It is apparent that the interest rates for municipal bonds with maturities of three to five years are fixed in accordance with regulations on interest rates of municipal bonds but in reality lower than real interest rates offered by commercial banks, which made these bonds less competitive and attractive than bank deposits, especially when inflation was high, effects of the 2008 global financial crisis were serious and sources of finance became scarcer.

\section{e. Issuance Costs:}


Costs include:

- Expenses in printing, preserving and storing bond certificates,

- Fee for issuance agencies at the maximum rate of $0.1 \%$ of the total value of bonds sold to investors,

- Underwriting fee equal to $0.15 \%$ of the total value underwritten,

- Fee for organizing bond bidding equal to $0.15 \%$ of the total value of winning bonds,

- Fee for agencies in charge of bond repayment equal to $0.1 \%$ of the total value of interest plus principal repaid, and

- Cost of the management and implementation of bond issuance, debt repayment and supervision of the use of capital raised from bonds equal to $0.2 \%$ of the total proceeds as stipulated by Article 13 of Decision 96/2003/QĐ-UB dated June 12, 2013 by HCMC People's Committee about promulgating regulations for municipal bond issuance.

Table 7: Bond Issuance Cost over the Period 2003-2012 (VND billion)

\begin{tabular}{cccc}
\hline \multirow{2}{*}{ Year } & Principal & \multicolumn{3}{c}{ Total Cost } \\
\cline { 3 - 4 } & & Interest & Maximum Issuance -Repayment Fee \\
\hline 2003 & 2,000 & 836.88 & 10.00 \\
2004 & 2,000 & $1,048.00$ & 9.46 \\
2005 & 2,000 & $1,858.50$ & 10.86 \\
2006 & 2,000 & $2,103.00$ & 11.10 \\
2007 & 2,000 & $1,921.75$ & 10.92 \\
2009 & 1,540 & 482.00 & 8.50 \\
2012 & 3,310 & $1,056.60$ & 18.08 \\
\hline Total & $\mathbf{1 4 , 8 5 0}$ & $\mathbf{9 , 3 0 6 . 7 3}$ & $\mathbf{7 8 . 9 1 6}$ \\
\hline
\end{tabular}

Source: Report of HCMC Investment Fund for Urban Development (HIFU) - Solutions to Raising Fund by Municipal Bond Issuance over the Years 2003-2012

Costs of bond issuance and repayment are determined in accordance with the guidelines provided by the Ministry of Finance and regulations for bond issuance promulgated by HCMC People's Committee. After issues, the issuers also consider competitive factors in order to reduce expense in raising bond fund and increase the efficiency of capital mobilization.

\section{f. Payment of Principal and Interest on Maturity:}


Financial resources to pay principal and interest of municipal bonds are from HCMC budget. For periodic payment of interest or principal, HCMC State Treasury transferred the money to Depository Center who sent it to customers through banks.

HCMC municipal bonds are a coupon type whose interest is paid once every six months at rate offered on issuance date while principal is paid once on maturity date. Actually, because bonds are issued by bidding on the stock exchange or underwriting, all differences in interest rates between the two methods, if any, only affect the repayment when investors make purchase of the bonds and cause no change in periodically paid rate.

Table 8: Payment of Principal and Interest of HCMC Municipal Bonds (VND billion)

\begin{tabular}{|c|c|c|}
\hline \multirow{2}{*}{ Year } & \multicolumn{2}{|c|}{ Budget of Payment } \\
\hline & Interest & Principal \\
\hline 2008 & 185.90 & 0 \\
\hline 2009 & 185.90 & 0 \\
\hline 2010 & 185.90 & 0 \\
\hline 2011 & 185.90 & 0 \\
\hline 2012 & 185.90 & 600 \\
\hline 2013 & 131.60 & 0 \\
\hline 2014 & 131.60 & 0 \\
\hline 2015 & 131.60 & 0 \\
\hline 2016 & 131.60 & 0 \\
\hline 2017 & 131.60 & 700 \\
\hline 2018 & 66.85 & 0 \\
\hline 2019 & 66.85 & 0 \\
\hline 2020 & 66.85 & 0 \\
\hline 2021 & 66.85 & 0 \\
\hline 2022 & 66.85 & 700 \\
\hline Total & $1,921.75$ & 2,000 \\
\hline
\end{tabular}


Source: HCMC Finance and Investment State-owned Company (HIFC)

It is estimated that from 2003 up to the present time, HCMC Treasury has made full payments of principal and interest to bondholders. Credit ratings and the attractiveness of municipal bonds significantly increase, enhancing liquidity of the bonds traded on the secondary market, which raises institutional investors' interest in biddings for large quantities of bonds. Additionally, the authorities always try to conduct bond repayment in accordance with the current regulations in a fast, safe, and most convenient manner to save costs for investors.

\section{g. Evaluation of Fund Raising from HCMC Municipal Bonds:}

- Strengths:

An analysis of fund raising from municipal bonds from 2003 until now shows that fundamental achievements are as follows:

First, an effective channel for raising capital for infrastructure projects in HCMC has been created.

Second, municipal bonds help increase sources of medium- and long-term capital and change local public debt structure from short term to longer term more appropriate to the needs for investment in socioeconomic development.

Third, municipal bonds becomes a source of high-quality commodities for financial markets.

Fourth, fund raising contributes to the stability of HCMC's financial and monetary situations.

- Weaknesses:

Compared to its potentials, municipal bond issuance suffers from many disadvantages, that is, it cannot sufficiently meet the demand for investment in infrastructure development in HCMC.

The plan for municipal bond issues is not sound and fails to achieve high efficiency.

HCMC municipal bonds are only general obligation ones, and the city has yet to issue revenue bonds.

- Causes of weaknesses:

- Macroeconomic environment is not favorable and many shortcomings remain. 
- The system of policies on fund raising through bonds in its pilot phase is not clarified and consistent, and lack efficiency, effectiveness and practicality, thereby causing difficulties to the implementation of policies.

- Mechanisms for determination of bond interest have not been clearly defined to be appropriate to market situation.

\section{BASIC MEASURES TO IMPROVE THE EFFICIENCY OF CAPITAL MOBILIZATION UNTIL 2020}

The measures taken should be systematic and diverse. However, due to the position and importance of each, these should be organized in the order of priority as follows:

\section{a. Measures for Market Development:}

To promote the development of municipal bond market, the following key measures should be taken:

- Develop the market for municipal bonds on the basis of linking primary offering market with secondary trading one, establish the standard interest curve for the market, provide information for the management and administration ${ }_{2}$ and simultaneously increase transparency for the trading market.

- In the near future, in order to ensure efficiency and reduce the cost of issuance, flexible forms of specified underwriting, underwriting with competitive fees and bidding with competitive interest rates through the stock exchange should be applied.

- Increase liquidity of municipal bonds on the secondary market, focusing on bond issuance in large lots.

- Develop bond repos and derivatives for the market.

- Concerning issuers, they should identify portfolio of the target debt, long-term costs and possible risks; organize markets for listing and trading bonds and conduct periodic issues with information publicly available.

\section{b. Establishment of Credit Ratings:}

Because of importance of credit rating agencies to the development of stock market in general and municipal bond market in particular, the following measures should be conducted to encourage establishment of such agencies:

- A decree on organization and operations of credit rating agencies is very necessary. 
- Regulations related to the operation of credit rating agencies should be consistent.

- Human resources for credit rating agencies should be prepared.

- International cooperation in the establishment of credit rating agencies in Vietnam is much needed.

In the context of Vietnam, the establishment of credit rating agencies and implementation of international cooperation are one of the indispensable prerequisites. Technical, financial and training assistance will help ensure trustworthiness for such organizations and newly established credit rating agencies should be under control of State Securities Commission.

In the long term, bond issuance should be improved as required by international practices, and issuers should get their trustworthiness rated by specialized agencies, which will then become an important channel of information to ensure objectivity, transparency and credibility for investors in their decisions on bond investment.

\section{c. Development of Diversified Commodities:}

- Introduction of revenue bonds: In the first phase, revenue bonds can be issued to finance specific projects. These funded projects should ensure reasonable payback periods. Besides revenue generated by the projects, revenue bonds are also settled by HCMC Treasury, which will enhance the credit ratings for revenue bonds. In the future, issues of revenue bonds by public utility companies could be linked with development projects underwritten by HCMC authorities.

- Increasing the volume of general obligation bonds by the following measures:

+ Renewing mechanism of fiscal delegation between central and local authorities.

+ Diversifying classes of general obligation bonds on the market to provide more commodities with high credit ratings.

General obligation bonds may have various types such as multi-term bonds, discount bonds, serial bonds, option bonds, and variable rate bonds.

\section{d. Interest Rate:}

Interest rate of municipal bonds needs to be determined according to the following basic criteria: 
- Adhering to the principles of market economy is necessary, so the determination of interest rate should follow the supply and demand relationship in the market. This rule can be implemented as bonds are issued with competitive bidding method.

- The longer the term lasts, the higher the interest rate is.

- It should be based on the interest rate of government bonds and current borrowing rate for deposits of similar term offered by commercial banks.

- Due to the limitations on power and HCMC budget income, the ability to settle municipal bonds is low in comparison with that of government bonds. Therefore, interest rate of municipal bonds should be higher than that of government bonds of the same term.

Regarding general obligation bonds issued directly by the city's authorities and secured by the city's budget income with low level of risk, interest rates of this kind is reasonably determined through competitive bidding whereby issuers offer the rates based on those of government bonds of the same term plus some risk premiums.

\section{e. Repayment Terms:}

Issuers are responsible for building a network of settlement agencies corresponding to issuance agencies to ensure convenience of bond repayments. At maturity date, HCMC Department of Finance shall transfer money to issuers to repay bondholders. Issuers or settlement agencies shall then directly repay principal and interest to bondholders.

Municipal bonds are listed and traded on the stock market; hence, interest and principal repayments to investors should be implemented uniformly through such agency as Depository Center to ensure convenience and reduce costs for issuers and investors. Regarding the method of bond repayment, the depository center shall transfer interest and principal payments to the accounts at the request of the bondholders

\section{References}

Bech-Hansen, J. (2002), Tax-Exempt Bond, Municipal Finance Officers Association of Ontario, Toronto.

Đinh Thế Hiển (2002), "Một số giải pháp trong việc sử dụng trái phiếu đô thị ở thành phố Hồ Chí Minh", paper presented at workshop "Trái phiếu đô thị ở Việt Nam: Triển vọng và phương thức phát hành". 
Harwood, A. (2000), Building Local Bond Markets: An Asian Perspective, Word Bank Publications.

Jia Kang (2002) "Study on Local Government Public Debt Financing in the People's Republic of China”, paper presented at ADB Conference on Local Government Finance and Bond Market Financing, available at www.adb.org/Documents/Events/2002/LG_Finance_Bond_Market/PRC_report.pdf

Leigland, J. (1997), “Accelerating Municipal Bond Market Development in Emerging Economies: An Assessment of Strategies and Progress", Public Budgeting \& Finance, Vol.17(2), pp.57-80.

Nguyễn Ngọc Thanh \& Trần Mạnh Kiên (2002), "Một số chính sách thúc đẩy thị trường trái phiếu đô thị ở Việt Nam", paper presented at workshop "Trái phiếu đô thị ở Việt Nam: Triển vọng và phương thức phát hành".

Peterson, G. (2000), Building Local Credit Systems, The World Bank

Peterson, G. (2002), Bank or Bond: Building a Municipal Credit Market, The Urban Institute, Washington D.C.

Phạm Phan Dũng (2002), “Triển vọng phát triển trái phiếu đô thị ở Việt Nam”, paper presented at workshop "Trái phiếu đô thị ở Việt Nam: Triển vọng và phương thức phát hành".

Phelps, P. (1997), Municipal Bond Market Development in Developing Countries: The Experience of the U.S, Agency for International Development, Research Triangle Institute, Washington D.C.

Steiss, A.W. (1975), Local Government Finance: Capital Facilities Planning and Debt Administration, Lexington Books.

Trần Đắc Sinh (2002), Định mức tín nhiệm tại Việt Nam, Thành phố Hồ Chí Minh Publisher.

Trần Đắc Sinh (2004), Huy động vốn đầu tư cơ sở hạ tầng qua thị trường chứng khoán. Thành phố Hồ Chí Minh Publisher.

Zipf, R. (1995), How Municipal Bonds Work, Prentice Hall Pr. 